\title{
Tree-Open Grassland Structure and Composition Drive Greenhouse Gas Exchange in Holm Oak Meadows of the Iberian Peninsula
}

\author{
Mercedes Ibañez ${ }^{1,2, * \mathbb{D}}$, María José Leiva ${ }^{3}$, Cristina Chocarro ${ }^{4}\left(\mathbb{D}\right.$, Salvador Aljazairi ${ }^{2}$, Àngela Ribas ${ }^{5,6}{ }^{(D)}$ and \\ Maria-Teresa Sebastià 1,2
}

1 Laboratory of Functional Ecology and Global Change, Forest Sciences Centre of Catalonia (CTFC), 25280 Solsona, Spain; teresa.sebastia@ctfc.es

2 GAMES Group \& Department HBJ, School of Agrifood and Forestry Science and Engineering (ETSEA), University of Lleida (UdL), 25198 Lleida, Spain; sal@ugr.es

3 Plant Biology and Ecology Department, University of Sevilla (US), 41080 Sevilla, Spain; leiva@us.es

4 Department of Crop and Forest Science and Agrotecnio-Center, School of Agrifood and Forestry Science and Engineering (ETSEA), University of Lleida (UdL), 25280 Lleida, Spain; cristina.chocarro@udl.cat

5 Centre for Ecological Research and Forestry Applications (CREAF), 08193 Bellaterra, Spain; a.ribas@creaf.uab.cat

6 Departamento de Biología Animal, de Biología Vegetal y de Ecología (BABVE), Edifici C, Universitat Autònoma de Barcelona, 08193 Bellaterra, Spain

* Correspondence: mercedes.ibanez@ctfc.es

Citation: Ibañez, M.; Leiva, M.J.; Chocarro, C.; Aljazairi, S.; Ribas, À.; Sebastià, M.-T. Tree-Open Grassland Structure and Composition Drive Greenhouse Gas Exchange in Holm Oak Meadows of the Iberian Peninsula. Agronomy 2021, 11, 50 . https://doi.org/10.3390/ agronomy11010050

Received: 4 November 2020 Accepted: 24 December 2020 Published: 28 December 2020

Publisher's Note: MDPI stays neutral with regard to jurisdictional claims in published maps and institutional affiliations.

Copyright: (c) 2020 by the authors. Licensee MDPI, Basel, Switzerland. This article is an open access article distributed under the terms and conditions of the Creative Commons Attribution (CC BY) license (https: / / creativecommons.org/ licenses/by/4.0/).

\begin{abstract}
Iberian holm oak meadows are savannah-like ecosystems that result from traditional silvo-pastoral practices. However, such traditional uses are declining, driving changes in the typical tree-open grassland structure of these systems. Yet, there are no studies integrating the whole ecosystem-including the arboreal and the herbaceous layer-as drivers of greenhouse gas (GHG: $\mathrm{CO}_{2}, \mathrm{CH}_{4}$ and $\mathrm{N}_{2} \mathrm{O}$ ) dynamics. Here, we aimed at integrating the influence of tree canopies and interactions among plant functional types (PFT: grasses, forbs, and legumes) of the herbaceous layer as GHG exchange drivers. For that purpose, we performed chamber-based GHG surveys in plots dominated by representative canopy types of Iberian holm oak meadows, including Quercus species and Pinus pinea stands, the last a common tree plantation replacing traditional stands, and unraveled GHG drivers through a diversity-interaction model approach. Our results show the tree-open grassland structure, especially drove $\mathrm{CO}_{2}$ and $\mathrm{N}_{2} \mathrm{O}$ fluxes, with higher emissions under the canopy than in the open grassland. Emissions under P. pinea canopies are higher than those under Quercus species. In addition, the inclusion of diversity and compositional terms of the herbaceous layer improve the explained variability, with legumes enhancing $\mathrm{CO}_{2}$ uptake and $\mathrm{N}_{2} \mathrm{O}$ emissions. Changes in the tree cover and tree species composition, in combination with changes in the structure and composition of the herbaceous layer, will imply deep changes in the GHG exchange of Iberian holm oak meadows. These results may provide some guidelines to perform better management strategies of this vast but vulnerable ecosystem.
\end{abstract}

Keywords: canopy; $\mathrm{CH}_{4} ; \mathrm{CO}_{2}$; dehesas; diversity-interaction model; $\mathrm{N}_{2} \mathrm{O}$; plant functional types (PFT)

\section{Introduction}

Holm oak meadows, also called dehesas in Spain and montados in Portugal, are seminatural savannah-like agroecosystems that result from the thinning of the Mediterranean forest, in which an herbaceous and an arboreal (mostly Quercus species) layer coexist. They are one of the largest agroforestry systems in Europe [1], covering 3.5-4 million ha, mostly along the South-West of the Iberian Peninsula [2], and are also present in other world regions with Mediterranean climate, mainly in California [3-5]. In addition, Mediterranean savannahs, with trees from other taxonomic groups, can be found in South 
Africa, south-western Australia, and central Chile [4]; and savannah-like ecosystems, in a broad sense, can be found worldwide, including mesquite grasslands in the United States, savanna ecosystems in Africa, and tropical savannas in Brazil (called cerrado). All of them, being ecosystems of high cultural, economic, and ecological value, are able to provide higher ecosystem services than open grasslands or field crops growing under similar conditions [6].

Holm oak meadows, in particular, have traditionally provided a wide variety of goods and services, including pasture for livestock, acorns, timber, and cork. However, such traditional uses that have shaped holm oak meadows into a matrix of trees and open grassland are changing, with the consequent implications that this may have on ecosystem functioning. Extensive grazing is declining towards intensive farming; plantations of fast-growing trees, mostly Eucalyptus and Pinus species; shrub encroachment due to land abandonment; and there is a worrying lack of tree regeneration $[7,8]$.

Hence, although the canopy influence has been described to some extent on soil [9-12], water fluxes [13], evapotranspiration [14], vegetation structure [15-17], and composition [4,18,19]; many fewer studies have assessed the influence of the tree-open grassland structure-on greenhouse gas (GHG: $\mathrm{CO}_{2}, \mathrm{CH}_{4}$, and $\mathrm{N}_{2} \mathrm{O}$ ) exchange. In this sense, studies conducted in Iberian holm oak meadows [17,20-24], as well as on other savannah-like ecosystems [25-28], have highlighted the relevance of the ecosystem structure as drivers of $\mathrm{CO}_{2}$ fluxes. However, some authors have described an enhanced soil respiration under the canopy compared to the open grassland (i.e., Tang and Baldocchi, 2005 [24]; Uribe et al., 2015 [20]), related to a higher soil C and N content, despite lower soil temperature, while others reported increased $\mathrm{CO}_{2}$ exchange rates in the open grassland, due to higher herbaceous biomass and light availability, as main drivers of $\mathrm{CO}_{2}$ uptake, and due to higher soil temperature, as main driver of $\mathrm{CO}_{2}$ release [17].

On the other hand, the only previous studies addressing $\mathrm{CH}_{4}$ and $\mathrm{N}_{2} \mathrm{O}$ exchange in Iberian holm oak meadows were conducted by Shvaleva et al., 2014 [29] and 2015 [30], which related $\mathrm{CH}_{4}$ and $\mathrm{N}_{2} \mathrm{O}$ emissions to soil water content, but the effect of soil water content (positive or negative) was dependent on the canopy [29]. In addition, $\mathrm{CH}_{4}$ and $\mathrm{N}_{2} \mathrm{O}$ assessments from other savannah-like ecosystems have identified the environment under the canopy as a possible source of $\mathrm{N}_{2} \mathrm{O}$ emissions [27,31]. Yet, $\mathrm{CH}_{4}$ and $\mathrm{N}_{2} \mathrm{O}$ assessments from savannah-like ecosystems, especially in Mediterranean environments, are still very scarce [32], and there is a lack of studies integrating the whole ecosystem structure and composition, combining the arboreal and the herbaceous layer (both profitable resources), and assessing how both interact to drive GHG exchange. Accordingly, it must be considered that the vegetation of the herbaceous layer of holm oak meadows is highly diverse [33], and sorting the wide variety of species of the herbaceous layer into plant functional types (PFT) may provide a mechanistic link between diversity and ecosystem functioning [34]. Indeed, most common (PFT) of the herbaceous layer, including grasses, non-legume forbs (hereafter "forbs"), and legume forbs (hereafter "legumes"), have different nitrogen (N) and light (and, therefore, $\mathrm{CO}_{2}$ ) use and acquisition strategies, which may result in different responses to tree canopies in their GHG exchange. In addition, most diversity-GHG studies have focused on the effect of specific or functional diversity on GHG dynamics [35,36], but much fewer have disentangled identity and interaction effects among PFT [37].

In the present study, we aimed at integrating the influence of trees and the herbaceous layer structure and composition as GHG exchange drivers. In particular, we aimed at (1) assessing the canopy effect under representative canopy types of Iberian holm oak meadows, including traditional Quercus species and Pinus pinea L. stands, the last a common tree plantation replacing traditional canopies; and (2) unraveling the influence of the main PFT of the herbaceous layer, using a diversity-interaction modeling approach. 


\section{Materials and Methods}

\subsection{Study Sites and Sampling Design}

Field work was carried out in spring (05/04/2016-10/04/2016) and autumn (13/12/$17 / 12 / 2016)$, coinciding with the most productive moments of the system, to capture seasonal variability of the studied variables and effects that may be season dependent. Study plots were distributed in two locations in the South-West of the Iberian Peninsula: Doñana Natural Park (DN, $37^{\circ} 15^{\prime} 34^{\prime \prime} \mathrm{N}, 6^{\circ} 19^{\prime} 55^{\prime \prime}$ W, $30 \mathrm{~m}$ a.s.l.) and Sierra Morena mountains (SM, $37^{\circ} 39^{\prime} 50^{\prime \prime} \mathrm{N}, 5^{\circ} 56^{\prime} 20^{\prime \prime} \mathrm{W}, 296 \mathrm{~m}$ a.s.l.). Both locations have Mediterranean climate regime with warm, dry summers, and mild winters [38]. Mean annual temperature in DN is $18.1^{\circ} \mathrm{C}$ and in $\mathrm{SM}$ is $16.8^{\circ} \mathrm{C}$, and mean annual precipitation in $\mathrm{DN}$ is $543 \mathrm{~mm}$ and in $\mathrm{SM}$ is $648 \mathrm{~mm}$. Grassland in both locations is dominated by herbaceous annual species, including grasses, non-legume forbs (hereafter "forbs"), and legume forbs (hereafter "legumes"). Both locations are extensively grazed at similar stocking rates: DN grazed by goat and cattle ( 0.40 livestock units (LSU) ha $\left.{ }^{-1}\right)$, and SM by cattle and Iberian pigs $\left(0.36 \mathrm{LSU}^{\mathrm{h}}{ }^{-1}\right.$ ).

To characterize soil properties of the study plots, soil samples were extracted and analyzed according to standard methods (Table 1). Texture in the SM-ilex plot varied from sandy clay loam $(0-40 \mathrm{~cm}$ depth) to clay $(40-80 \mathrm{~cm}$ depth). All DN soils had a sandy clay loam texture, except the deeper layer of the DN-suber plot, which was sandy loam. The $\mathrm{SM}$-ilex plot had a slightly acid $\mathrm{pH}$ and $\mathrm{DN}$ plots had a neutral-basic $\mathrm{pH}$. Organic $\mathrm{C}$ was very low in all the plots (Table 1), although the value in the first $30 \mathrm{~cm}$ of the DN-pinea plot was markedly above the average. Total $\mathrm{N}$ was in general also quite low (Table 1).

Table 1. Soil characteristics per plot and depth. Soil analysis performed according to: $\mathrm{pH}$ [39], organic C [40], total N (Elemental analyzer-measuring the total amounts of nitrogen, carbon and Sulfur (CNS methodology)—Trumac, LECO Corporation, St. Joseph, MI, USA) and texture [41].

\begin{tabular}{ccccccccc}
\hline Plot & \multicolumn{2}{c}{ SM-ilex } & \multicolumn{2}{c}{ DN-mixed } & \multicolumn{2}{c}{ DN-suber } & \multicolumn{2}{c}{ DN-pinea } \\
\hline Depth (cm) & $\mathbf{0 - 4 0}$ & $\mathbf{4 0 - 8 0}$ & $\mathbf{0 - 3 0}$ & $\mathbf{3 0 - 6 0}$ & $\mathbf{0 - 3 0}$ & $\mathbf{3 0 - 6 0}$ & $\mathbf{0 - 3 0}$ & $\mathbf{3 0 - 6 0}$ \\
\hline pH & 6.7 & 7.2 & 7.9 & 7.8 & 7.5 & 7.8 & 7.0 & 7.4 \\
Organic C (\%) & 0.80 & 0.30 & 0.32 & 0.34 & 0.60 & 0.02 & 1.52 & 0.51 \\
Total N (\%) & 0.85 & 0.60 & 0.15 & 0.04 & 0.06 & 0.05 & 0.20 & 0.11 \\
Clay (\%) & 18 & 30 & 10 & 11 & 13 & 4 & 16 & 16 \\
Silt (\%) & 29 & 28 & 25 & 15 & 18 & 9 & 22 & 21 \\
Sand (\%) & 54 & 42 & 65 & 74 & 69 & 87 & 62 & 63 \\
\hline
\end{tabular}

Study plots were selected according to their tree composition, with representative canopy types of Iberian holm oak meadows. One pure Q. ilex stand, in the SM location (SMilex), and one pure $Q$. suber stand in the $\mathrm{DN}$ location (DN-suber), both the most abundant stands; one Q. ilex and Q. suber mixed stand (DN-mixed), the next most abundant; and a pure Pinus pinea L. stand (DN-pinea), a common tree plantation replacing traditional canopies [7]. Plot tree densities (trees ha ${ }^{-1}$ ) were $34 \pm 1$ in SM-ilex, $26 \pm 1$ in DN-mixed, $26 \pm 4$ in DN-suer, and $48 \pm 6$ DN-pinea. Study treatments were, therefore, established according to plot (SM-ilex, DN-mixed, DN-suber, and DN-pinea), season (spring and autumn), and canopy (open grassland, OG, and under the canopy, UC).

Tree individuals of the UC treatment of each species were selected with a similar diameter at breast height $(\mathrm{DBH}, Q$. ilex $0.43 \pm 0.03$, Q. suber $0.63 \pm 0.03$ and P. pinea $0.57 \pm 0.06 \mathrm{~m}$ ). In addition, sampling points of the UC treatment were always placed at $1 \mathrm{~m}$ distance from the selected tree trunk, and sampling points of the OG treatment were placed at a minimal distance of $3 \mathrm{~m}$ from the selected tree, clearly outside the canopy, to minimize the influence of stem water flow. Sampling points were systematically placed following the north orientation with respect to the tree trunks.

For each treatment level, we selected 3-4 replicates, totaling 73 sampling points. In the DN-mixed plot, we discriminated between both Quercus species (Q. suber and Q. ilex) to establish sampling points. However, preliminary comparative analysis in the DN-mixed 
plot on environmental and vegetation characteristics under the canopy of both Quercus species indicated no relevant differences. DN-mixed plot results are then always presented, combining both tree species.

At each sampling point, we hammered a metal collar, which was necessary for measuring GHG exchange (Section 2.2), and that defined the area in which vegetation (Section 2.3) and soil (Section 2.4) were sampled.

\subsection{Greenhouse Gas Exchange (GHG) Measurements}

To measure GHG exchange, including $\mathrm{CO}_{2}, \mathrm{CH}_{4}$, and $\mathrm{N}_{2} \mathrm{O}$, we used a portable gasexchange system, consisting of a cylindrical chamber (volume $=0.019 \mathrm{~m}^{3}$ ), connected to a photoacoustic spectroscopy gas analyzer (PAS, INNOVA 1412, LumaSense Technologies, Denmark; see further system set-up details in Debouk et al., 2018). PAS nominal detection limit is 5, 0.24, and 0.03 ppm for $\mathrm{CO}_{2}, \mathrm{CH}_{4}$, and $\mathrm{N}_{2} \mathrm{O}$, respectively [42]. PAS was calibrated prior to field campaigns by the vendor in the customary way [43].

The cylindrical chamber was secured to the ground by fixing it to metal collars $(\mathrm{h}=$ $8 \mathrm{~cm}$, diameter $=25 \mathrm{~cm})$, previously hammered into the ground $(3 \mathrm{~cm}$ deep) at least $24 \mathrm{~h}$ before each measurement, to limit disturbances to the soil-vegetation system. In addition, we inspected any possible disturbance on the soil that could have caused an increase on GHG emissions, but no disturbance was detected, neither during the current survey nor in previous PAS surveys [44].

Flux measurements were done placing the chamber consecutively over the metal collars for five minutes. Measurements were done over intact vegetation, at light and dark (by covering the chamber) conditions. Afterwards, the vegetation inside the metal collar was harvested, and bare soil measurements at dark conditions were also performed, at least two hours after harvesting. As a result, 219 flux measurements (considering all treatment levels and replicates -73 sampling points $-\times 3$ different conditions) were recorded.

In the case of $\mathrm{CO}_{2}$, resulting fluxes measured over vegetation at light conditions can be approximated as the understory net ecosystem $\mathrm{CO}_{2}$ exchange (NEE); over vegetation at dark conditions can be approximated as ecosystem respiration $\left(\mathrm{R}_{\mathrm{eco}}\right)$; and, on bare soil at dark conditions, can be approximated as soil respiration $\left(\mathrm{R}_{\text {soil }}\right)$. In the case of $\mathrm{CH}_{4}$ and $\mathrm{N}_{2} \mathrm{O}$, we did not detect significant differences among measuring conditions. Therefore, we present the average value considering all three measuring conditions [44].

Flux measurements, flux calculation, and data quality checks were done according to Debouk et al. (2018). This included a fitting goodness assessment based on the $\mathrm{R}_{\text {Adj }}{ }^{2}$ value (fluxes below a $\mathrm{R}_{\text {Adj }}{ }^{2}$ of 0.8 for $\mathrm{CO}_{2}$, and below 0.2 for $\mathrm{CH}_{4}$ and $\mathrm{N}_{2} \mathrm{O}$, were excluded), and filtering fluxes below flux detection limit, calculated as the standard deviation of the ambient concentration over the measuring time. Negative values refer to the flux from the atmosphere to the biosphere and positive values correspond to the flux from the biosphere to the atmosphere, according to the micrometeorological sign convention [45].

Ancillary meteorological variables, including photosynthetically active radiation (PAR) outside the chamber (AccuPAR model LP-80 PAR/LAI ceptometer, Decagon Devices, Inc., Washington, D.C., USA); air temperature $\left(\mathrm{T}_{\mathrm{a}}\right)$ inside and outside the chamber (multi-logger thermometer, TMD-56, Amprove, Washington, D.C., USA); soil temperature $\left(\mathrm{T}_{\mathrm{S}}\right) 1-10 \mathrm{~cm}$; and soil water content (SWC, gravimetric method, Section 2.4) were recorded to calculate and model GHG fluxes, as well as to characterize microclimatic sampling conditions (summarized in Figure S1).

\subsection{Vegetation Sampling}

After GHG measurements were made, we harvested the vegetation at ground level at each sampling point. Thereafter, in the laboratory, we separated the vegetation into aboveground biomass (AGB) and litter (dead plant material detached from the herbaceous vegetation and tree leaves on soil surface). All fractions are summarized in Figure S2. In addition, we separated the AGB into PFT (forbs, grasses, and legumes, summarized in Figure S3). Vegetation was oven dried at $60{ }^{\circ} \mathrm{C}$ until constant weight. 


\subsection{Belowground Biomass Sampling and Soil Water Content Determination}

Two soil cores of $9 \mathrm{~cm}^{2}$ surface and $0-10 \mathrm{~cm}$ depth were extracted at each sampling point. In the laboratory, one of the cores was washed and filtered with a $0.2 \mathrm{~mm}$ pore size strainer to obtain belowground biomass (BGB, summarized in Figure S2). The second core was used for SWC determination by gravimetric method, as the difference between fresh and dry soil weight. Both, BGB and soil samples were oven dried at $60{ }^{\circ} \mathrm{C}$ until constant weight.

\subsection{Data Analysis: Greenhouse Gas Exchange Modeling}

To assess main GHG $\left(\mathrm{CO}_{2}, \mathrm{CH}_{4}\right.$ and $\left.\mathrm{N}_{2} \mathrm{O}\right)$ drivers, especially focusing on the influence of trees and the herbaceous layer structure and composition, we run a diversity-interaction modeling [46,47]. The modeling compares a null model, in which the response variable is not affected by plant diversity and/or composition, to models that address diversity and composition at different levels. In our study, we compared the null model (Equation (1)), in which the corresponding GHG depended only on treatment variables, including plot, season, and canopy; environmental variables, including PAR ( $\mu \mathrm{mol}$ photons $\mathrm{m}^{-2} \mathrm{~s}^{-1}$ ), temperature $\left(\mathrm{T},{ }^{\circ} \mathrm{C}\right)$, and SWC (fraction); and structural components of the herbaceous layer, including $\mathrm{AGB}$, litter, and $\mathrm{BGB}\left(\mathrm{g} \mathrm{DW} \mathrm{m}^{-2}\right)$ :

Null model

$$
\begin{aligned}
\mathrm{GHG}=\beta_{\text {Plot }} \text { Plot } & +\beta_{\text {Season Season } \times} \times \beta_{\text {Canopy Canopy }}+\beta_{\mathrm{T}} \mathrm{T}+\beta_{\mathrm{SWC}} \mathrm{SWC}+\beta_{\mathrm{PAR}} \mathrm{PAR}+\beta_{\mathrm{AGB}} \mathrm{AGB} \\
& +\beta_{\text {Litter Litter }}+\beta_{\mathrm{BGB}} \mathrm{BGB}+\varepsilon
\end{aligned}
$$

to models that included PFT composition and diversity of the herbaceous layer in different ways:

(a) Identity model, which includes PFT identity effects, meaning the biomass proportion of each PFT (Equation (2)), where $P$ indicates the proportion of the given PFT and the sub-index $F$ indicates forbs, $G$ grasses, and $L$ legumes, respectively: Identity model

$$
\text { GHG }=\text { Null model }+\beta_{F} P_{F}+\beta_{G} P_{G}+\beta_{L} P_{L}+\varepsilon
$$

(b) Average interaction model, which includes PFT identity effects, plus evenness [46] as an average interaction term (Equation (3)). Evenness $(E)$ calculated as $E=$ $\left(\frac{2 \mathrm{PFT}}{(\mathrm{PFT}-1)}\right) \sum_{i<j}^{\mathrm{PFT}} P_{i} P_{j}$, where PFT is the number of PFT present in the community, and $P_{i}$ the relative abundance of the PFTs. Evenness lies between 0 for mono-PFT plots, and 1 when all PFT are equally represented. Average interaction model

$$
\text { GHG }=\text { Null model }+\beta_{F} P_{F}+\beta_{G} P_{G}+\beta_{L} P_{L}+\text { evenness }+\varepsilon
$$

(c) Specific interaction model, which includes specific interactions between PFT in addition to the identity effects (Equation (4)): Specific interaction model

$$
\text { GHG }=\text { Null model }+\beta_{F} P_{F}+\beta_{G} P_{G}+\beta_{L} P_{L}+\beta_{F G} P_{F} P_{G}+\beta_{F L} P_{F} P_{L}+\beta_{G L} P_{G} P_{L}+\beta_{F G L} P_{F} P_{G} P_{L}+\varepsilon
$$

The models were run without intercept to test the effect of all three PFT at the same time [46]. In addition, we modeled all microclimatic sampling conditions (PAR, $\mathrm{T}_{\mathrm{s}}$, and SWC, summarized in Table S1) and vegetation fractions (AGB, litter, BGB, and PFT, summarized in Table S2), as function of plot, season, and canopy. To compare and determine the final model in each case, we used several methods, including Akaike information criteria (AIC), the adjusted determination coefficient $R^{2}\left(R^{2}\right.$ adj $)$, and model comparison by analysis of variance (ANOVA) to test significant differences between models, using the "anova" function in R. The ANOVA comparison between models tested whether the reduction in the residual sum of squares was statistically significant [48]. The most explicative and parsimonious model of each GHG is shown and discussed. The modeling of microclimatic sampling conditions and vegetation fractions was used to interpret and discuss our results. 


\section{Results}

Tree canopies drove microclimatic conditions (Figure S1 and Table S1), as well as the structure (Figure S2) and composition (Figure S3 and Table S2) of the herbaceous layer. Factors, in combination with season, interacted among them to drive GHG fluxes. PAR and $\mathrm{T}_{\mathrm{S}}$ decreased under the canopy compared to the open grassland, being this difference less marked in autumn than in spring (Figure S1 and Table S1). The structure and composition of the herbaceous layer was also dependent on the presence of tree canopies. The green fraction (AGB) slightly decreased under the canopy compared to the open grassland in all DN plots (Figure S2 and Table S2). Reduction that was mostly due to a change in the PFT composition, with the biomass of forbs and legumes decreasing under the canopy compared to the open grassland (Figure S3 and Table S2). On the contrary, such change in the AGB between the under the canopy and the open grassland was not noticeable in the SM-ilex plot (Figure S2 and Table S2). The litter fraction was markedly higher under the canopy than in the open grassland, although this difference almost disappeared in autumn (Figure S2 and Table S2).

\section{1. $\mathrm{CO}_{2}$ Exchange}

$\mathrm{CO}_{2}$ net uptake was similar in spring and autumn (NEE, Figure $1 \mathrm{~A}$ ), while $\mathrm{CO}_{2}$ emissions $\left(R_{\text {eco }}\right.$ and $R_{\text {soil }}$, Figure $1 \mathrm{~A}$ ) were lower in autumn than in spring (season effect, Table 2). The SM-ilex plot showed the highest net $\mathrm{CO}_{2}$ uptake rates (NEE, Figure $1 \mathrm{~A}$ ) and the highest $R_{\text {eco }}$ rates in the open grassland (Figure $1 \mathrm{~A}$ ), while DN-pinea was the plot with the highest $\mathrm{CO}_{2}$ emissions under the canopy $\left(\mathrm{R}_{\text {eco }}\right.$ and $\mathrm{R}_{\text {soil }}$, Figure $\left.1 \mathrm{~A}\right)$.

A

OG
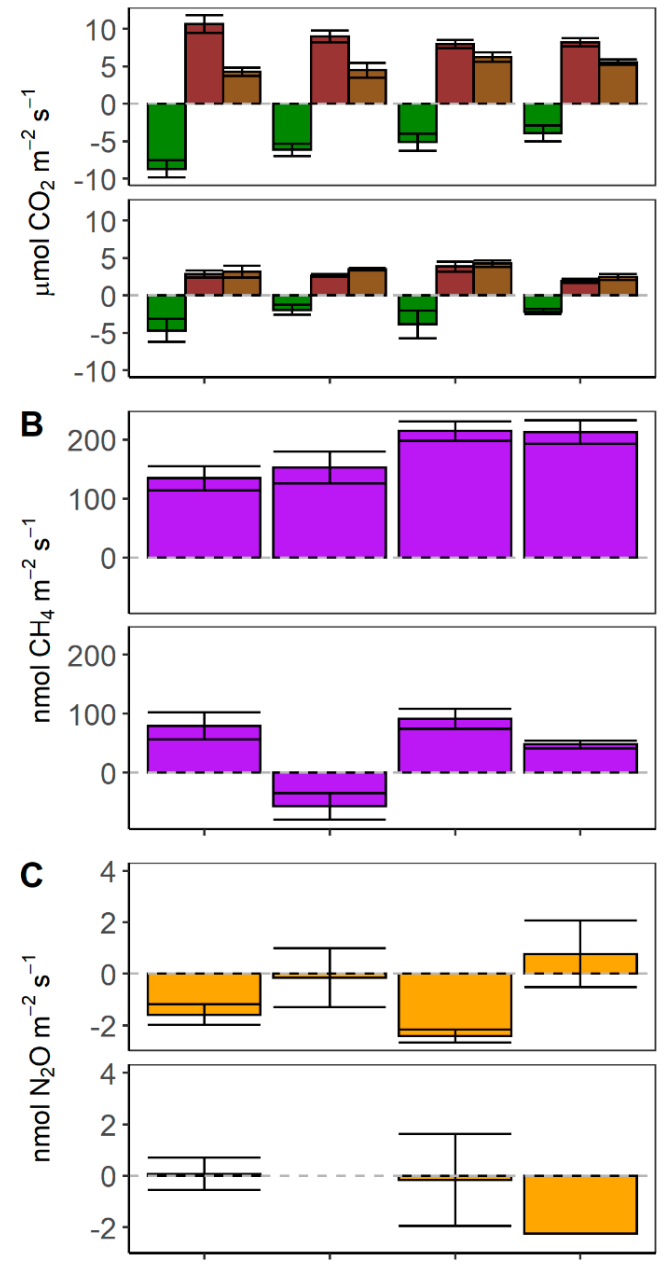

SM-ilex DN-mixed DN-suber DN-pinea
UC
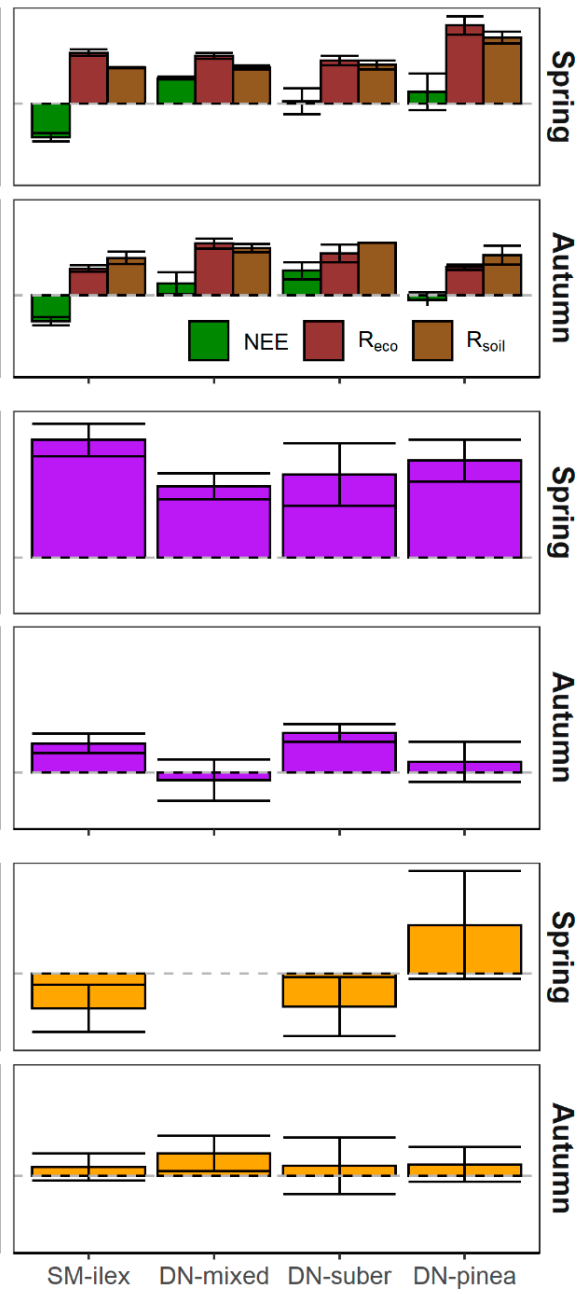

Figure 1. Greenhouse gas exchange per plot, season, and canopy: open grassland (OG) and under the canopy (UC). (A) Net ecosystem $\mathrm{CO}_{2}$ exchange (NEE, green), ecosystem respiration ( $\mathrm{R}_{\text {eco, }}$ garnet), and soil respiration $\left(\mathrm{R}_{\text {soil }}\right.$, brown); $(\mathbf{B}) \mathrm{CH}_{4}$ (purple); and (C) $\mathrm{N}_{2} \mathrm{O}$ (yellow) exchange. Mean \pm standard error. 
Table 2. $\mathrm{CO}_{2}$ exchange diversity-interaction model results. Net ecosystem exchange (NEE), ecosystem respiration ( $\left.\mathrm{R}_{\mathrm{eco}}\right)$, and soil respiration $\left(\mathrm{R}_{\text {soil }}\right)$ as function of plot, season, canopy, photosynthetically active radiation (PAR), air temperature $\left(\mathrm{T}_{\mathrm{a}}\right.$ ), aboveground biomass (AGB), belowground biomass (BGB), and plant functional types (forbs, grasses, and legumes) proportions. Season with spring as reference level, and canopy with open grassland (OG) as reference level. Parameter estimates (Par.), standard error (SE), t, and $p$-value.

\begin{tabular}{|c|c|c|c|c|c|c|c|c|c|c|c|c|}
\hline \multicolumn{13}{|c|}{ 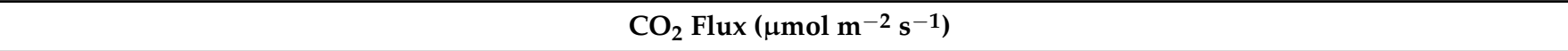 } \\
\hline & \multicolumn{4}{|c|}{ NEE } & \multicolumn{4}{|c|}{$\mathbf{R}_{\text {eco }}$} & \multicolumn{4}{|c|}{$\mathbf{R}_{\text {soil }}$} \\
\hline & \multicolumn{4}{|c|}{ Specific Interaction Model } & \multicolumn{4}{|c|}{ Null Model } & \multicolumn{4}{|c|}{ Null Model } \\
\hline & Par. & SE & $\mathbf{t}$ & $p$-Value & Par. & SE & $\mathbf{t}$ & $p$-Value & Par. & SE & $\mathbf{t}$ & $p$-Value \\
\hline Plot SM-ilex & -6 & 3 & -1.81 & 0.07 & 8.9 & 0.6 & 14.60 & $<0.001$ & 0 & 1 & 0.35 & 0.7 \\
\hline $\begin{array}{c}\text { Plot } \\
\text { DN-mixed }\end{array}$ & -2 & 3 & -0.54 & 0.6 & 9.0 & 0.5 & 18.82 & $<0.001$ & 1 & 1 & 0.55 & 0.6 \\
\hline $\begin{array}{c}\text { Plot } \\
\text { DN-suber }\end{array}$ & -2 & 3 & -0.57 & 0.6 & 8.6 & 0.6 & 13.74 & $<0.001$ & 2 & 1 & 1.33 & 0.2 \\
\hline $\begin{array}{c}\text { Plot } \\
\text { DN-pinea }\end{array}$ & -1 & 3 & -0.38 & 0.7 & 9.2 & 0.6 & 14.69 & $<0.001$ & 1 & 1 & 0.65 & 0.5 \\
\hline Season & & & & & -6.2 & 0.6 & -9.88 & $<0.001$ & -1.3 & 0.5 & -2.56 & 0.01 \\
\hline Canopy & 4 & 0.7 & 5.58 & $<0.001$ & -1.8 & 0.6 & -2.98 & 0.004 & 1.1 & 0.5 & 2.10 & 0.04 \\
\hline $\begin{array}{l}\text { Season } \mathrm{x} \\
\text { canopy }\end{array}$ & & & & & 4.3 & 0.9 & 4.73 & $<0.001$ & 1.8 & 0.7 & 2.40 & 0.02 \\
\hline $\begin{array}{c}\text { PAR ( } \mu \mathrm{mol} \\
\text { photons } \\
\left.\mathrm{m}^{-2} \mathrm{~s}^{-1}\right)\end{array}$ & -0.003 & 0.001 & -4.58 & $<0.001$ & & & & & & & & \\
\hline $\mathrm{T}_{\mathrm{a}}\left({ }^{\circ} \mathrm{C}\right)$ & & & & & & & & & 0.15 & 0.05 & 3.06 & 0.003 \\
\hline $\begin{array}{c}\text { BGB (g DW } \\
\left.\mathrm{m}^{-2}\right)\end{array}$ & & & & & & & & & 0.0015 & 0.0007 & 2.21 & 0.03 \\
\hline $\begin{array}{c}\text { Forbs } \\
\text { (fraction) }\end{array}$ & 0 & 3 & 0.15 & 0.9 & & & & & & & & \\
\hline $\begin{array}{l}\text { Grasses } \\
\text { (fraction) }\end{array}$ & -1 & 3 & -0.22 & $<0.001$ & & & & & & & & \\
\hline $\begin{array}{l}\text { Legumes } \\
\text { (fraction) }\end{array}$ & -67 & 17 & -3.97 & $<0.001$ & & & & & & & & \\
\hline $\begin{array}{l}\text { Forbs } \times \\
\text { legumes } \\
\text { (fraction) }\end{array}$ & 97 & 25 & 3.84 & $<0.001$ & & & & & & & & \\
\hline $\begin{array}{c}\text { Grasses } \times \\
\text { legumes } \\
\text { (fraction) }\end{array}$ & 96 & 24 & 4.07 & $<0.001$ & & & & & & & & \\
\hline
\end{tabular}

Thus, the canopy itself had a strong influence over $\mathrm{CO}_{2}$ fluxes. Generally, NEE under the canopy was dominated by $\mathrm{CO}_{2}$ emissions (canopy effect, $\mathrm{t}=5.58, p<0.001$, Table 2), NEE being strongly driven by PAR (PAR effect, $\mathrm{t}=-4.58, p<0.001$, Table 2). The exception was the $\mathrm{SM}$-ilex plot, where there was net $\mathrm{CO}_{2}$ uptake under the canopy, instead of emissions (NEE, Figure 1A).

On the other hand, $\mathrm{R}_{\text {eco }}$ decreased under the canopy compared to the open grassland in spring but increased under the canopy in autumn (season $x$ canopy effect, $t=4.73$, $p<0.001$, Table 2). $\mathbf{R}_{\text {soil }}$ increased under the canopy, especially in autumn (season $\mathrm{x}$ canopy effect, $\mathrm{t}=2.40, p=0.02$, Table 2), $\mathrm{R}_{\text {soil }}$ being enhanced by $\mathrm{T}_{\mathrm{a}}\left(\mathrm{T}_{\mathrm{a}}\right.$ effect, $\mathrm{t}=3.06, p=0.003$, Table 2) and BGB (BGB effect, $\mathrm{t}=2.21, p=0.03$, Table 2).

Moreover, PFT composition drove significantly NEE. The most parsimonious and explanatory model was a specific interaction model (Equation (4)). Legumes enhanced net $\mathrm{CO}_{2}$ uptake (NEE, legumes effect, $\mathrm{t}=-3.97, p<0.001$, Table 2 and Figure 2), which slightly decreased with the addition of forbs (forbs $\times$ legumes effect, $t=3.84, p<0.001$, Table 2) and grasses (grasses $\times$ legumes effect, $t=4.07, p<0.001$, Table 2 ) in the mixture. 

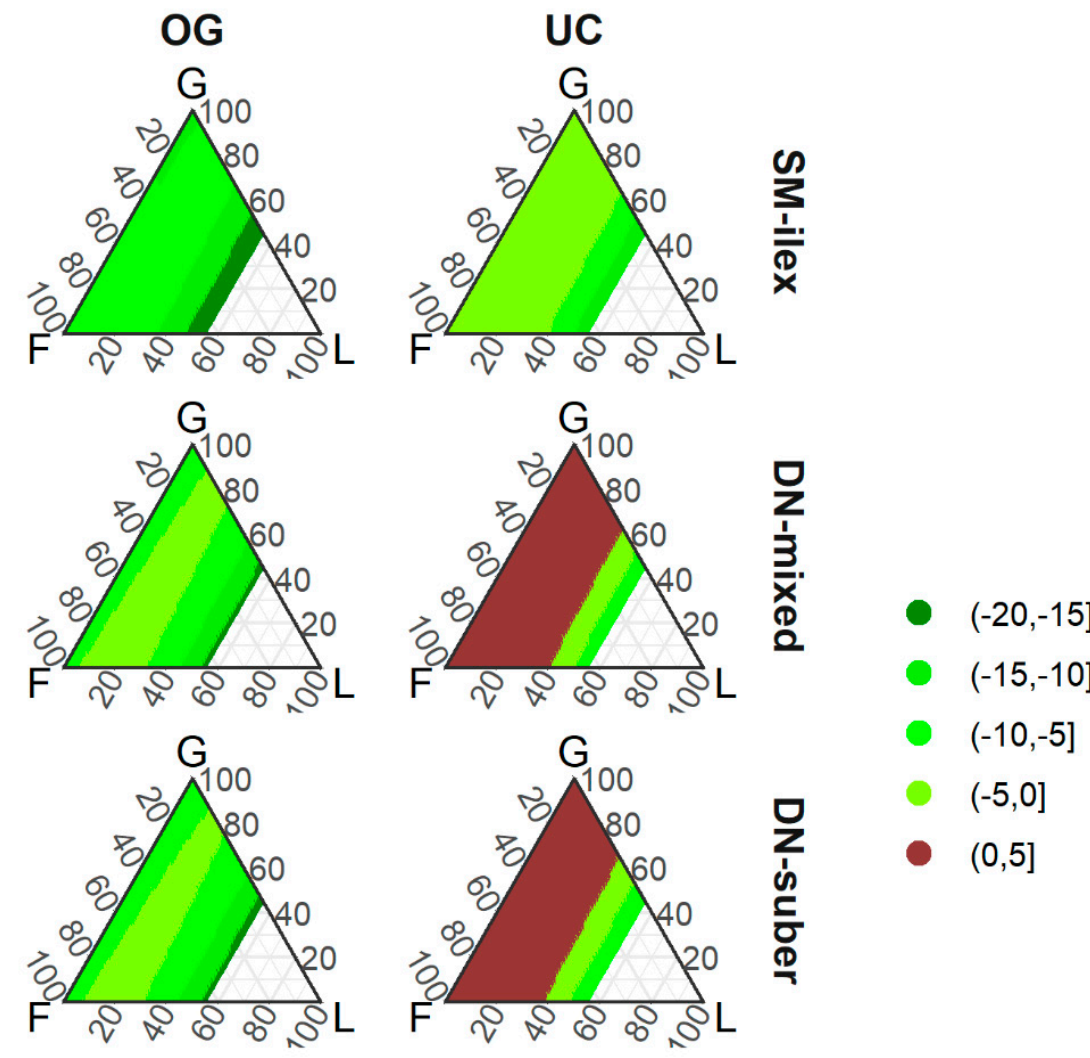

동
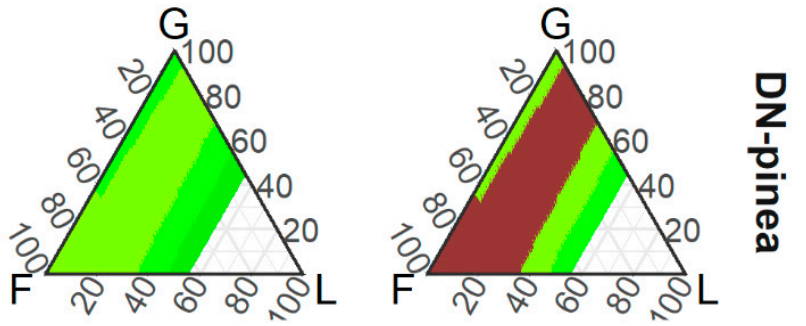

Figure 2. Predicted net ecosystem exchange (NEE, $\mu \mathrm{mol} \mathrm{CO} \mathrm{CO}^{-2} \mathrm{~s}^{-1}$ ) according to the specific interaction model (Table 2). F indicates forbs, G grasses, and L legumes. Predicted NEE modeled with a maximum proportion of legumes of $50 \%$, according to the legumes proportion observed in the field (Figure S3). Negative NEE values indicate net $\mathrm{CO}_{2}$ uptake, and positive values indicate $\mathrm{CO}_{2}$ emissions. Environmental conditions set as the mean of the given treatment level.

\section{2. $\mathrm{CH}_{4}$ and $\mathrm{N}_{2} \mathrm{O}$ Exchange}

$\mathrm{CH}_{4}$ emissions were lower in autumn than in spring (season effect, $\mathrm{t}=-9.68, p<$ 0.001 , Table 3 ) and were enhanced by $\mathrm{T}_{\mathrm{s}}\left(\mathrm{T}_{\mathrm{s}}\right.$ effect, $\mathrm{t}=2.72, p=0.008$, Table 3 ) and SWC (marginally significant SWC effect, $\mathrm{t}=1.83, p=0.07$, Table 3 ). 
Table 3. $\mathrm{CH}_{4}$ and $\mathrm{N}_{2} \mathrm{O}$ exchange diversity-interaction model results. $\mathrm{CH}_{4}$ and $\mathrm{N}_{2} \mathrm{O}$ exchange as function of plot, season, canopy, soil temperature $\left(\mathrm{T}_{\mathrm{s}}\right)$, soil water content (SWC), litter, belowground biomass (BGB), and plant functional types (forbs, grasses, and legumes) proportions. Season with spring as reference level, and canopy with open grassland (OG) as reference level. Parameter estimates (Par.), standard error (SE), t, and $p$-value.

\begin{tabular}{|c|c|c|c|c|c|c|c|c|}
\hline & \multicolumn{4}{|c|}{$\mathrm{CH}_{4}\left(\mathrm{nmol} \mathrm{m}^{-2} \mathrm{~s}^{-1}\right)$} & \multicolumn{4}{|c|}{$\mathrm{N}_{2} \mathrm{O}\left(\mathrm{nmol} \mathrm{m}^{-2} \mathrm{~s}^{-1}\right)$} \\
\hline & \multicolumn{4}{|c|}{ Null Model } & \multicolumn{4}{|c|}{ Identity Model } \\
\hline & Par. & $\mathrm{SE}$ & $\mathbf{t}$ & $p$-Value & Par. & SE & $\mathbf{t}$ & $p$-Value \\
\hline Plot SM-ilex & -24 & 81 & -0.30 & 0.8 & & & & \\
\hline Plot DN-mixed & -83 & 81 & -1.03 & 0.3 & & & & \\
\hline Plot DN-suber & -22 & 85 & -0.26 & 0.8 & & & & \\
\hline Plot DN-pinea & -28 & 85 & -0.33 & 0.7 & & & & \\
\hline Season spring & & & & & -13 & 5 & -2.73 & 0.008 \\
\hline Season autumn & -150 & 15 & -9.68 & $<0.001$ & -11 & 5 & -2.30 & 0.03 \\
\hline Canopy & & & & & 2.1 & 0.8 & 2.68 & 0.010 \\
\hline $\mathrm{T}_{\mathrm{S}}\left({ }^{\circ} \mathrm{C}\right)$ & 13 & 5 & 2.72 & 0.008 & 0.4 & 0.2 & 2.44 & 0.02 \\
\hline SWC (fraction) & 1.4 & 0.8 & 1.83 & 0.07 & -0.05 & 0.03 & -2.00 & 0.05 \\
\hline Litter (g DW m $\left.{ }^{-2}\right)$ & -0.1 & 0.1 & -1.89 & 0.06 & 0.007 & 0.003 & 2.84 & 0.006 \\
\hline BGB $\left(\mathrm{g} \mathrm{DW} \mathrm{m}^{-2}\right)$ & & & & & 0.002 & 0.001 & 1.75 & 0.09 \\
\hline Forbs (fraction) & & & & & 3 & 3 & 1.02 & 0.3 \\
\hline Grasses (fraction) & & & & & 2 & 3 & 0.47 & 0.6 \\
\hline Legumes (fraction) & & & & & 10 & 4 & 2.49 & 0.02 \\
\hline
\end{tabular}

$\mathrm{N}_{2} \mathrm{O}$ fluxes were uptake dominated in spring, except in the DN-pinea plot, where there were emissions both under the canopy and in the open grassland (Figure 3). Under the canopy $\mathrm{N}_{2} \mathrm{O}$ fluxes tend to increase (canopy effect $\mathrm{t}=2.68, p=0.01$, Table 3 ), especially in autumn (Figure 3). $\mathrm{N}_{2} \mathrm{O}$ emissions also increased with litter (litter effect, $\mathrm{t}=2.84, p=0.006$, Table 3). Moreover, PFT composition of the herbaceous layer drove significantly $\mathrm{N}_{2} \mathrm{O}$ fluxes, being the most parsimonious and explanatory model an identity model (Equation (2)), with the presence of legumes significantly enhancing $\mathrm{N}_{2} \mathrm{O}$ emissions (legumes effect, $\mathrm{t}=2.49$, $p=0.02$, Table 3 and Figure 3).
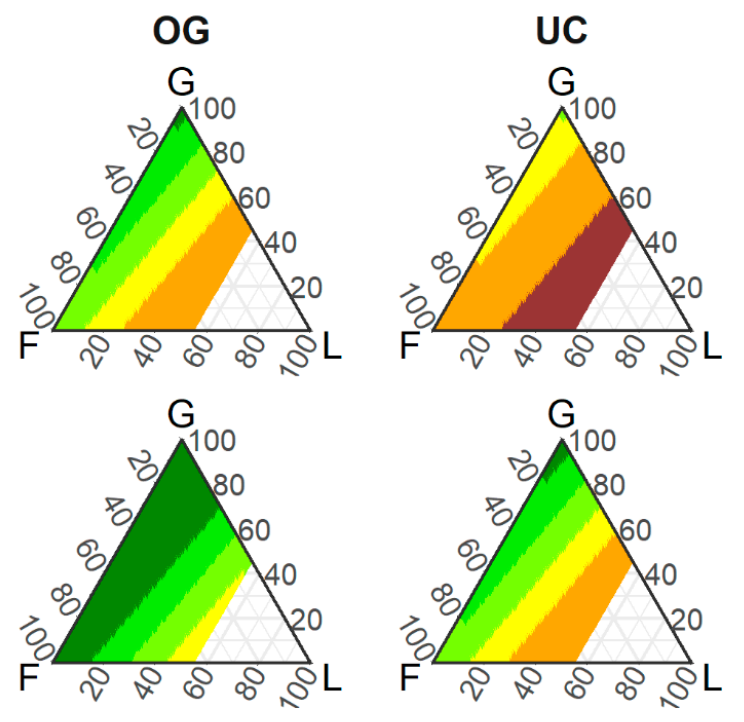

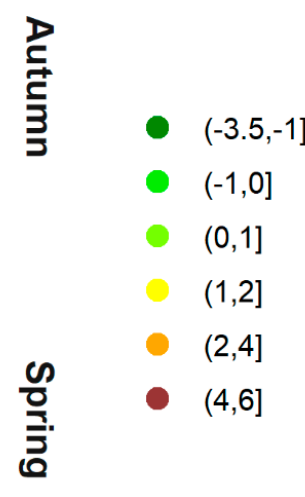

Figure 3. Predicted $\mathrm{N}_{2} \mathrm{O}$ exchange ( $\mathrm{nmol} \mathrm{m}^{-2} \mathrm{~s}^{-1}$ ) according to the identity model (Table 3). F indicates forbs, $\mathrm{G}$ grasses, and $\mathrm{L}$ legumes. Predicted $\mathrm{N}_{2} \mathrm{O}$ modeled with a maximum proportion of legumes of $50 \%$, according to the legumes proportion observed in the field (Figure S3). Negative $\mathrm{N}_{2} \mathrm{O}$ values indicate net uptake, and positive values indicate $\mathrm{N}_{2} \mathrm{O}$ emissions. Environmental conditions set as the mean of the given treatment level. 


\section{Discussion}

\section{1. $\mathrm{CO}_{2}$ Exchange Drivers}

Our results highlight the relevance of tree canopies as drivers of $\mathrm{CO}_{2}$ exchange, with NEE being uptake dominated in the open grassland in all the study plots, while, under the canopy, there were emissions in all DN plots (Figure 1A). These results support the well-known effect of light as driver of $\mathrm{CO}_{2}$ uptake, as well as agree with previous $\mathrm{CO}_{2}$ assessments in Mediterranean holm oak meadows [17,26,49] and other savannahlike ecosystems $[25,28,50,51]$ that identified an enhancement of $\mathrm{CO}_{2}$ emissions under the canopy compared to the open grassland. However, note that, in the SM-ilex, there was net $\mathrm{CO}_{2}$ uptake under the canopy instead of emissions (Figure $1 \mathrm{~A}$ ), which interestingly suggests a differential canopy effect between locations (DN vs. SM). Thus, although the light reduction under the canopy in the SM-ilex plot was in the same range of magnitude than in all DN plots (Figure S1), the vegetation in the SM-ilex plot took up $\mathrm{CO}_{2}$ at similar rates, both under the canopy and in the open grassland (Figure 1A). This might be related to the aboveground biomass (AGB) in the SM-ilex, which was similar under the canopy and in the open grassland, in comparison to a certain AGB reduction observed under the canopy in all DN plots (Figure S2 and Table S2). In line with this differential canopy effect between locations (SM vs. DN), Ibañez (2019) [52] reported that forbs from the same study plots presented more ${ }^{13} \mathrm{C}$-depleted tissues under the canopy than in the open grassland in all DN plots, while this depletion was not noticeable in the SM-ilex plot. A fact that indicate that the vegetation was photosynthesizing at similar rates under the canopy and in the open grassland in the SM-ilex plot, while the photosynthetic rate differed in the DN plots. This suggests that, in the SM-ilex plot, the environment created under the canopy does not differ so much to the open grassland, in opposition to the strong differences found in DN, and emphasizes the relevance of the canopy effect in more environmentally constrained holm oak meadows, as is the case of DN compared to SM.

The inclusion of PFT composition and diversity improved NEE's explained variability and highlights the relevance of specific PFT identity and interaction effects (Table 2 and Figure 2), which were even more explicative than the AGB. Legumes were key NEE drivers, enhancing net $\mathrm{CO}_{2}$ uptake (Table 2 and Figure 2), in agreement with previous studies that reported higher photosynthetic capacity of legumes compared to grasses and forbs [53-56], resulting in higher net $\mathrm{CO}_{2}$ uptake [57]. In addition, legumes have the ability to transfer symbiotic $\mathrm{N}$ to other species, increasing photosynthetic rates of the overall community [58,59], and, at the same time, the acquisition of symbiotic $\mathrm{N}$ by legumes can be stimulated by the presence of grasses [60]. Accordingly, $\mathrm{N}$ fixed by legumes could be an important source of soil fertility [61] and provide an advantage for photosynthesis, especially in $\mathrm{N}$ limited systems, as might be the case of our plots, with very low soil $\mathrm{N}$ content (Table 1).

The tree-open grassland structure also drove ecosystem respiration dynamics $\left(R_{\text {eco, }}\right.$ Figure 1A), but this effect was dependent on season and the magnitude of $R_{\text {eco }}$ components $\left(R_{\text {eco }}=R_{\text {autotrophic }}+R_{\text {heterotrophic }}\right)$. In spring, the lower $R_{\text {eco }}$ rates under the canopy compared to the open grassland were the result of a lower temperature $\left(T_{\mathrm{S}}\right.$ effect, Table 2), which is known to be an important $R_{\text {eco }}$ driver [17], especially enhancing the heterotrophic component of $R_{\text {eco }}$ [62]. In addition, enhanced $R_{\text {eco }}$ rates in spring and in the open grassland could also be indirectly related to increased gross $\mathrm{CO}_{2}$ uptake rates, increasing markedly $R_{\text {autotrophic }}$ rates $[63,64]$. In autumn conversely, the increased respiration rates $\left(R_{\text {eco }}\right.$ and $\left.R_{\text {soil }}\right)$ recorded under the canopy compared to the open grassland (canopy $\times$ season, Table 2 ) were probably related to litter decomposition processes, increasing the heterotrophic component of $R_{\text {eco }}$. The big amount of litter that was present under the canopy in spring was no longer present in autumn (Figure S2), suggesting that litter was already incorporated into the soil, and that it was probably a mineralization process. Respiratory fluxes, $R_{\text {eco }}$ and $R_{\text {soil }}$, were also both influenced by the structure of the herbaceous layer, enhanced by the belowground biomass (BGB effect, Table 2), which has been directly linked to auto and heterotrophic respiration [65-67]. 
Moreover, our data also interestingly suggested that respiration rates $\left(\mathrm{R}_{\mathrm{eco}}\right.$ and $\left.\mathrm{R}_{\text {soil }}\right)$ under P. pinea canopies were higher than under Quercus species (Figure 1A, spring). This might be because the canopy of P. pinea is more open than that of Quercus species, with lower leaf area index [68], resulting in the lowest buffering of PAR (Figure S1A), and the lowest buffering of $\mathrm{T}_{\mathrm{S}}$ among all DN plots (Figure $\mathrm{S1B}$ ) under the canopy, conditions that could be enhancing respiration rates. In addition, litter of $P$. pinea has been reported to be richer in carbon I content than that of Quercus species $[69,70]$, which could be increasing soil organic $C$ at the plot level (Table 1), and the carbon, nitrogen ratio in the soil under the canopy, as reported by Ibañez (2019) [52] from the same study plots. This, leading to enhanced $R_{\text {heterotrophic }}$ rates, since soil organic $C$ has been positively related to $\mathrm{CO}_{2}$ emissions [71]; in addition, microorganisms respire more $C$ when decomposing $C$-rich and/or N-poor substrates [72].

\section{2. $\mathrm{CH}_{4}$ and $\mathrm{N}_{2} \mathrm{O}$ Exchange Drivers}

Although there are some $\mathrm{CH}_{4}$ and $\mathrm{N}_{2} \mathrm{O}$ assessments from savannah-like ecosystems (i.e., Herman et al., 2003 [31]; McLain et al., 2008 [51]; McLain and Martens, 2006 [27]), this type of surveys from Mediterranean holm oak meadows are very scarce [32], and our study provides one of the first GHG datasets of the Iberian Peninsula, unraveling the mechanisms behind these fluxes. $\mathrm{CH}_{4}$ emissions were driven by seasonality rather than by the holm oak meadow structure and composition. $\mathrm{CH}_{4}$ shifted from high emissions in spring, to low emissions or uptake in autumn (Figure 1B), probably as result of several factors combined. First, $\mathrm{CH}_{4}$ emissions in spring (Figure $\left.1 \mathrm{~B}\right)$ were enhanced by temperature $\left(\mathrm{T}_{\mathrm{s}}\right.$ effect, Table 3), which could be favoring methanogenic activity and methane diffusion [32]. And second, SWC enhanced $\mathrm{CH}_{4}$ emissions (although marginally significant, Table 2), which, in combination with drying-rewetting cycles, typical in spring, could also be enhancing $\mathrm{CH}_{4}$ soil emissions [73].

On the other hand, we reported $\mathrm{N}_{2} \mathrm{O}$ emissions under the canopy in autumn, which could be the result of relatively high soil temperatures and soil moisture $\left(\mathrm{T}_{\mathrm{S}}\right.$ and SWC effect, Table 3, and see the range of these variables in Figure S1), in combination with organic matter mineralization (see litter effect, Table 3, and the decrease in the litter fraction in autumn compared to spring, Figure S2). Those factors are known to enhance nitrification and denitrification processes, resulting in $\mathrm{N}_{2} \mathrm{O}$ emissions [74]. In agreement, other studies have also reported higher $\mathrm{N}_{2} \mathrm{O}$ emissions under the canopy in combination with high temperatures and soil water moisture [27,51], as well as higher $\mathrm{N}_{2} \mathrm{O}$ emissions linked to a higher $\mathrm{N}$ availability and higher $\mathrm{N}$-cycling rates under the canopy than in the open grassland [31]. Interestingly, the DN-pinea plot performed again higher GHG fluxes, with enhanced $\mathrm{N}_{2} \mathrm{O}$ emissions in spring (Figure 1C) compared to plots dominated by Quercus species. The lower buffering effect of P. pinea canopy on PAR (Figure S1A) and $\mathrm{T}_{\mathrm{S}}$ (Figure S1B), and the higher soil organic $\mathrm{C}$ of the plot (Table 1), combined with higher soil $\mathrm{N}$ content under the canopy [52], could be enhancing $\mathrm{N}_{2} \mathrm{O}$ emissions. In agreement, Liu et al. (2014) [71] reported a positive relationship between soil organic $C$, soil $N$, and $\mathrm{N}_{2} \mathrm{O}$ emissions. However, the role of different tree species modifying soil properties, and this, in turn driving $\mathrm{N}_{2} \mathrm{O}$ dynamics, needs further investigation.

Moreover, $\mathrm{N}_{2} \mathrm{O}$ exchange was influenced by the structure and composition of the herbaceous layer, increasing $\mathrm{N}_{2} \mathrm{O}$ emissions with litter and the presence of legumes in the community (Table 3). The influence of litter on $\mathrm{N}_{2} \mathrm{O}$ exchange at field conditions is not well understood, but there are some experiments assessing the effect of cover crops on $\mathrm{N}_{2} \mathrm{O}$ exchange that may provide some understanding [75-77]. For instance, an experimental study by Shaaban et al. (2016) [77] reported increasing $\mathrm{N}_{2} \mathrm{O}$ emissions with the addition of litter onto soil surface. The authors related the input of organic matter to stimulated microbial activity and denitrification, resulting in $\mathrm{N}_{2} \mathrm{O}$ production [77]. In addition, $\mathrm{N}_{2} \mathrm{O}$ emissions have been negatively correlated to the $\mathrm{C} / \mathrm{N}$ ratio of the substrate [77]. Findings that agree with our results of legumes enhancing $\mathrm{N}_{2} \mathrm{O}$ emissions (Table 3 and Figure 3 ). 


\subsection{Management Implications}

Holm oak meadows are productive ecosystems, and any management strategy must take that into account. In this regard, our results suggest that an increase in the tree cover may reduce the net $\mathrm{CO}_{2}$ sink capacity of the understory, while also reduce forage production and quality. Under the canopy, there is a reduction on net $\mathrm{CO}_{2}$ uptake rates compared to the open grassland, via (a) a direct canopy effect (especially in DN, Table 2), with the corresponding implications that this may have on forage production; and (b) an indirect effect through changes in the herbaceous layer composition. The latter related to a decrease in the presence of legumes under the canopy (Figure S3), which were enhancing net $\mathrm{CO}_{2}$ uptake rates (NEE, Table 2 and Figure 2). With the implications that this may have on forage quality. Therefore, it is highly advisable to preserve open grassland spaces to maximize net $\mathrm{CO}_{2}$ uptake and preserve forage provision. In addition, a change in the tree species composition, shifting from Quercus species stands to Pinus species plantations may increase $\mathrm{CO}_{2}$ (Figure 1A) and $\mathrm{N}_{2} \mathrm{O}$ (Figure 1B) emissions, being highly advisable to preserve traditional Quercus, stands to minimize $\mathrm{CO}_{2}$ and $\mathrm{N}_{2} \mathrm{O}$ emissions.

\section{Conclusions}

Our study provides insight into Iberian holm oak meadows functioning, integrating the arboreal and the herbaceous layer structure and composition as GHG drivers. Tree canopies, especially, drove $\mathrm{CO}_{2}$ and $\mathrm{N}_{2} \mathrm{O}$ fluxes, increasing emissions under P. pinea canopy compared to that of Quercus species. The inclusion of the herbaceous layer composition and diversity terms improved explained variability, legumes enhancing net $\mathrm{CO}_{2}$ uptake and $\mathrm{N}_{2} \mathrm{O}$ emissions. Thus, PFT identity and interaction effects were even more explanatory than some structural components (i.e., aboveground biomass). Changes in the tree cover and species will imply significant changes in the GHG exchange of Iberian holm oak meadows mediated by changes in the structure and composition of the herbaceous layer. This may provide some keys to improve ecosystem services provision and guarantee the preservation of this vast but vulnerable ecosystem.

Supplementary Materials: The following are available online at https://www.mdpi.com/2073-4 395/11/1/50/s1, Figure S1. Microclimatic sampling conditions per plot, season, and canopy: open grassland (OG) and under the canopy (UC). (A) Photosynthetically active radiation (PAR); (B) soil temperature $\left(\mathrm{T}_{\mathrm{S}}\right)$ and; $(\mathrm{C})$ soil water content $(\mathrm{SWC})$. Boxplot's midline indicates the median; upper and lower limits of the box indicate the third and first quartile; whiskers extend up to 1.5 times the interquartile range from the top/bottom of the respective box, and points represent data beyond the whiskers. Figure S2. Mean \pm SE of aboveground biomass (AGB), litter and belowground biomass (BGB) per plot, season, and canopy: open grassland (OG) and under the canopy (UC). Figure S3. Mean \pm SE of plant functional types (PFT: forbs, grasses, and legumes) per plot, season, and canopy: open grassland (OG) and under the canopy (UC). Table S1. Microclimatic conditions linear modeling results, as function of plot, season, and canopy. Photosynthetically active radiation (PAR), soil temperature $\left(T_{\mathrm{S}}\right)$ and soil water content $(\mathrm{SWC})$. Plot with SM-ilex as reference level, season with spring as reference level, and canopy with open grassland (OG) as reference level. Parameter estimates (Par.), standard error (SE), $\mathrm{t}$ and $p$-value. Table S2. Herbaceous layer structure and composition linear modeling results, as function of plot, season, and canopy. Aboveground biomass (AGB), litter and plant functional types (PFT) biomass: forbs, grasses, and legumes. Season with spring as reference level, plot with SM-ilex as reference level, and canopy with open grassland (OG) as reference level. Parameter estimates (Par.), standard error (SE), $t$ and $p$-value. BGB was quite variable among treatments (Figure S2), and neither season, plot or canopy explained its variability. Linear modeling on BGB is not shown.

Author Contributions: Conceptualization, M.I., M.-T.S., and M.J.L.; methodology, M.I., M.-T.S., M.J.L., C.C., and S.A.; formal analysis, M.I. and C.C.; investigation, M.I.; writing-original draft preparation, M.I., M.-T.S., M.J.L.; writing—review and editing, M.I., M.-T.S., M.J.L., C.C., À.R., S.A.; supervision, M.-T.S.; project administration, M.-T.S. and M.J.L.; funding acquisition, M.-T.S. and M.J.L. All authors have read and agreed to the published version of the manuscript. 
Funding: This work was funded by the Spanish Science Foundation FECYT-MINECO: BIOGEI (GL2013-49142-C2-1-R) and IMAGINE (CGL2017-85490-R) projects and supported by a FPI fellowship to Mercedes Ibañez (BES-2014-069243).

Institutional Review Board Statement: Not applicable.

Informed Consent Statement: Not applicable.

Data Availability Statement: The data presented in this study are available on request from the corresponding author. Data are not public as the database is currently being used for other research projects.

Acknowledgments: Thanks to all the colleagues who collaborated in laboratory and fieldwork tasks: Antonio Rodríguez, Miquel Sala, Helena Sarri and Gianluca Segalina. Our special thanks to Dehesa de Gato S.L. state and Doñana Research Coordination Office for their support and facilities.

Conflicts of Interest: The authors declare no conflict of interest.

\section{References}

1. $\quad$ Eichhorn, M.P.; Paris, P.; Herzog, F.; Incoll, L.D.; Liagre, F.; Mantzanas, K.; Mayus, M.; Moreno, G.; Papanastasis, V.P.; Pilbeam, D.J.; et al. Silvoarable systems in Europe - Past, present and future prospects. Agrofor. Syst. 2006, 67, 29-50. [CrossRef]

2. Olea, L.; López-Bellido, R.J.; Poblaciones, M. Europe types of silvopastoral systems in the Mediterranean area: Dehesa. In Silvopastoralism and Sustainable Land Management. In Proceedings of the International Congress on Silvopastoralism and Sustainable Management, Lugo, Spain, 18-24 April 2004; Mosquera-Losada, M.R., Rigueiro-Rodríguez, A., McAdam, J., Eds.; CAB International: Wallingford, Oxfordshire, UK, 2005; pp. 30-35.

3. Huntsinger, L.; Campos, P.; Starrs, P.F.; Oviedo, J.L.; Díaz, M.; Standiford, R.B.; Gregorio, M. Working Landscapes of the Spanish Dehesa and California Oak Woodlands: An Introduction. In Mediterranean Oak Woodland Working Landscapes. Dehesas of Spain and Ranchlands of California; Campos, P., Huntsinger, L., Oviedo, J.L., Starrs, P.F., Diaz, M., Standiford, R.B., Montero, G., Eds.; Springer: New York, NY, USA, 2013; pp. 3-23. ISBN 978-94-007-6706-5.

4. Marañón, T.; Pugnaire, F.I.; Callaway, R.M. Mediterranean-climate oak savannas: The interplay between abiotic environment and species interactions. Web Ecol. 2009, 9, 30-43. [CrossRef]

5. Gaman, T.; Firman, J. Oaks 2040: The Status and Future of Oaks in California; California Oak Foundation: Oakland, CA, USA, 2006.

6. Mohan Kumar, B.; Ramachandran Nair, P.K. (Eds.) Carbon Sequestration Potential of Agroforestry Systems; Springer: Berlin, Germany, 2011; ISBN 9789400716308.

7. Costa Pérez, J.C.; Martín Vicente, Á.; Fernández Alés, R.; Estirado Oliet, M.; Montes, I.D.; Medio, C.D. Dehesas de Andalucía. Caracterización Ambiental; Consejería de Medio Ambiente, Junta de Andalucía, Eds.; Tecnographic, S.L.: Sevilla, Spain, 2006; ISBN 849632981X.

8. Costa, A.; Madeira, M.; Lima Santos, J.; Oliveira, Â. Change and dynamics in Mediterranean evergreen oak woodlands landscapes of Southwestern Iberian Peninsula. Landsc. Urban Plan. 2011, 102, 164-176. [CrossRef]

9. Howlett, D.S.; Moreno, G.; Mosquera Losada, M.R.; Nair, P.K.R.; Nair, V.D. Soil carbon storage as influenced by tree cover in the Dehesa cork oak silvopasture of central-western Spain. J. Environ. Monit. 2011, 13, 1897-1904. [CrossRef]

10. Gómez-Rey, M.X.; Madeira, M.; Gonzalez-Prieto, S.J.; Coutinho, J. Soil C and N dynamics in a Mediterranean oak woodland with shrub encroachment. Plant Soil 2013, 371, 339-354. [CrossRef]

11. Pulido-Fernández, M.; Schnabel, S.; Lavado-Contador, J.F.; Miralles Mellado, I.; Ortega Pérez, R. Soil organic matter of Iberian open woodland rangelands as influenced by vegetation cover and land management. Catena 2013, 109, 13-24. [CrossRef]

12. Andivia, E.; Fernández, M.; Alejano, R.; Vázquez-Piqué, J. Tree patch distribution drives spatial heterogeneity of soil traits in cork oak woodlands. Ann. For. Sci. 2015, 549-559. [CrossRef]

13. Baldocchi, D.D.; Xu, L.; Kiang, N. How plant functional-type, weather, seasonal drought, and soil physical properties alter water and energy fluxes of an oak-grass savanna and an annual grassland. Agric. For. Meteorol. 2004, 123, 13-39. [CrossRef]

14. Ma, S.; Eichelmann, E.; Wolf, S.; Rey-Sanchez, C.; Baldocchi, D.D. Transpiration and evaporation in a Californian oak-grass savanna: Field measurements and partitioning model results. Agric. For. Meteorol. 2020, 295, 1-13. [CrossRef]

15. Gea-Izquierdo, G.; Montero, G.; Cañellas, I. Changes in limiting resources determine spatio-temporal variability in tree-grass interactions. Agrofor. Syst. 2009, 76, 375-387. [CrossRef]

16. Moreno, G.; Obrador, J.J.; García, A. Impact of evergreen oaks on soil fertility and crop production in intercropped dehesas. Agric. Ecosyst. Environ. 2007, 119, 270-280. [CrossRef]

17. Hussain, M.Z.; Otieno, D.O.; Mirzae, H.; Li, Y.L.; Schmidt, M.W.T.; Siebke, L.; Foken, T.; Ribeiro, N.A.; Pereira, J.S.; Tenhunen, J.D. $\mathrm{CO}_{2}$ exchange and biomass development of the herbaceous vegetation in the Portuguese montado ecosystem during spring. Agric. Ecosyst. Environ. 2009, 132, 143-152. [CrossRef]

18. Rossetti, I.; Bagella, S.; Cappai, C.; Caria, M.C.; Lai, R.; Roggero, P.P.; Martins, P.; Sousa, J.P.; Querner, P.; Seddaiu, G. Isolated cork oak trees affect soil properties and biodiversity in a Mediterranean wooded grassland. Agric. Ecosyst. Environ. 2015, 202, 203-216. [CrossRef] 
19. Lopez-Carrasco, C.; Lopez-Sanchez, A.; San Miguel, A.; Roig, S. The effect of tree cover on the biomass and diversity of the herbaceous layer in a Mediterranean dehesa. Grass Forage Sci. 2015, 70, 639-650. [CrossRef]

20. Uribe, C.; Inclán, R.; Hernando, L.; Román, M.; Clavero, M.A.; Roig, S.; Van Miegroet, H. Grazing, tilling and canopy effects on carbon dioxide fluxes in a Spanish dehesa. Agrofor. Syst. 2015, 89, 305-318. [CrossRef]

21. Casals, P.; Gimeno, C.; Carrara, A.; Lopez-sangil, L. Soil $\mathrm{CO}_{2}$ efflux and extractable organic carbon fractions under simulated precipitation events in a Mediterranean Dehesa. Soil Biol. Biochem. 2009, 41, 1915-1922. [CrossRef]

22. Casals, P.; Sangil, L.L.; Carrara, A.; Gimeno, C.; Nogués, S. Autotrophic and heterotrophic contributions to short-term soil $\mathrm{CO}_{2}$ efflux following simulated summer precipitation pulses in a Mediterranean dehesa. Global Biogeochem. Cycles 2011, 25, 1-12. [CrossRef]

23. Ma, S.; Baldocchi, D.D.; Xu, L.; Hehn, T. Inter-annual variability in carbon dioxide exchange of an oak/grass savanna and open grassland in California. Agric. For. Meteorol. 2007, 147, 157-171. [CrossRef]

24. Tang, J.; Baldocchi, D.D. Spatial-temporal variation in soil respiration in an oak-grass savanna ecosystem in California and its partitioning into autotrophic and heterotrophic components. Biogeochemistry 2005, 73, 183-207. [CrossRef]

25. Barron-Gafford, G.A.; Scott, R.L.; Jenerette, G.D.; Huxman, T.E. The relative controls of temperature, soil moisture, and plant functional group on soil $\mathrm{CO}_{2}$ efflux at diel, seasonal, and annual scales. J. Geophys. Res. 2011, 116, 1-16. [CrossRef]

26. Li, Y.L.; Tenhunen, J.; Mirzaei, H.; Hussain, M.Z.; Siebicke, L.; Foken, T.; Otieno, D.; Schmidt, M.; Ribeiro, N.; Aires, L.; et al. Assessment and up-scaling of $\mathrm{CO} 2$ exchange by patches of the herbaceous vegetation mosaic in a Portuguese cork oak woodland. Agric. For. Meteorol. 2008, 148, 1318-1331. [CrossRef]

27. McLain, J.E.T.; Martens, D.A. Moisture Controls on Trace Gas Fluxes in Semiarid Riparian Soils. Soil Sci. Soc. Am. J. 2006, 70, 367-377. [CrossRef]

28. Fan, Z.; Neff, J.C.; Hanan, N.P. Modeling pulsed soil respiration in an African savanna ecosystem. Agric. For. Meteorol. 2015, 200, 282-292. [CrossRef]

29. Shvaleva, A.; Costa, F.; Costa, J.M.; Correia, A.; Anderson, M.; Lobo-do-vale, R.; Fangueiro, D.; Bicho, C. Comparison of methane, nitrous oxide fluxes and $\mathrm{CO}_{2}$ respiration rates from a Mediterranean cork oak ecosystem and improved pasture. Plant Soil 2014, 374, 883-898. [CrossRef]

30. Shvaleva, A.; Siljanen, H.M.P.; Correia, A.; Silva, F.C.; Lamprecht, R.E.; Lobo-do-Vale, R.; Bicho, C.; Fangueiro, D.; Anderson, M.; Pereira, J.S.; et al. Environmental and microbial factors influencing methane and nitrous oxide fluxes in Mediterranean cork oak woodlands: Trees make a difference. Front. Microbiol. 2015, 6, 1-11. [CrossRef]

31. Herman, D.; Halverson, L.; Firestone, M. Nitrogen dynamics in an annual grassland: Oak canopy, climate, and microbial population effects. Ecol. Appl. 2003, 13, 593-604. [CrossRef]

32. Oertel, C.; Matschullat, J.; Zurba, K.; Zimmermann, F.; Erasmi, S. Greenhouse gas emissions from soils-A review. Chem. Erde 2016, 76, 327-352. [CrossRef]

33. Marañon, A. Diversidad floristica y heterogenidad ambiental en una dehesa de Sierra Morena. Edafol. Agro-Biol. 1985, 44, 1183-1197.

34. Petchey, O.L.; Gaston, K.J. Functional diversity: Back to basics and looking forward. Ecol. Lett. 2006, 9, 741-758. [CrossRef]

35. De Deyn, G.B.; Quirk, H.; Yi, Z.; Oakley, S.; Ostle, N.J.; Bardgett, R.D. Vegetation composition promotes carbon and nitrogen storage in model grassland communities of contrasting soil fertility. J. Ecol. 2009, 97, 864-875. [CrossRef]

36. Niklaus, P.A.; Wardle, D.A.; Tate, K.R. Effects of plant species diversity and composition on nitrogen cycling and the trace gas balance of soils. Plant Soil 2006, 83-98. [CrossRef]

37. Ribas, A.; Llurba, R.; Gouriveau, F.; Altimir, N.; Connolly, J.; Sebastià, M.T. Plant identity and evenness affect yield and trace gas exchanges in forage mixtures. Plant Soil 2015, 391, 93-108. [CrossRef]

38. Peel, M.C.; Finlayson, B.L.; McMahon, T.A. Updated world map of the Köppen-Geiger climate classification. Hydrol. Earth Syst. Sci. 2007, 11, 1633-1644. [CrossRef]

39. Porta Casanellas, J.; López-Acevedo Reguerín, M.; Rodríguez Ochoa, R. Determinación de pH y conductividad eléctrica en extractos acuosos 1/5 (p/v). In Técnicas y Experimentos en Edafología; Col-legi Oficial d'Enginyers Agrònoms de Catalunya, Ed.; Col·legi d'Enginyers Agrònoms de Catalunya, Universidad Politécnica de Cataluña, Escola Tècnica Superior d'Enginyers Agrònoms de Lleida: Lleida, Spain, 1986.

40. Walkley, A.; Black, C.A. An examination of the Degtjareff method for determining soil organic matter and a proposed modification of the chromic acid titration method. Soil Sci. 1934, 37, 29-38. [CrossRef]

41. Gee, G.W.; Bauder, J.W. Particle size analysis. In Methods of Soil Analysis. Part 1; Klute, A., Ed.; Soil Science Society of America, Inc.: Madison, WI, USA, 1986; pp. 383-409.

42. LumaSense Technologies Gas Detection Limits. Available online: https://www.advancedenergy.com/globalassets/resourcesroot/diagrams--charts/en-gs-innova-detection-limit-tables.pdf (accessed on 10 December 2020).

43. Moody, L.B.; Li, H.; Burns, R.T.; Xin, H.; Gates, R.S.; Hoff, S.J.; Overhults, D.G. A quality assurance project plan for monitoring gaseous and particulate matter emissions from broiler housing. Am. Soc. Agric. Biol. Eng. 2008, 1-27. [CrossRef]

44. Debouk, H.; Altimir, N.; Sebastià, M.T. Maximizing the information obtained from chamber-based greenhouse gas exchange measurements in remote areas. MethodsX 2018, 5, 973-983. [CrossRef]

45. Eddy Covariance. A Practical Guide to Measurement and Data Analysis; Aubinet, M.; Vesala, T.; Papale, D. (Eds.) Springer: Dordrecht, The Netherlands; London, UK; New York, NY, USA, 2012; ISBN 9789400723504. 
46. Kirwan, L.; Lüscher, A.; Sebastià, M.T.; Finn, J.A.; Collins, R.P.; Porqueddu, C.; Helgadottir, A.; Baadshaug, O.H.; Brophy, C.; Coran, C.; et al. Evenness drives consistent diversity effects in intensive grassland systems across 28 European sites. J. Ecol. 2007, 95, 530-539. [CrossRef]

47. Kirwan, L.; Connolly, J.; Finn, J.A.; Brophy, C.; Lüscher, A.; Nyfeler, D.; Sebastia, M.-T. Diversity-interaction modeling: Estimating contributions of species identities and interactions to ecosystem function. Ecology 2009, 90, 2032-2038. [CrossRef]

48. Fabozzi, F.J.; Focardi, S.M.; Rachev, S.T.; Arshanapalli, B.G. Appendix E: Model Selection Criterion: AIC and BIC. In The Basics of Financial Econometrics: Tools, Concepts, and Asset Management Applications; John Wiley \& Sons, Inc.: Hoboken, NJ, USA, 2014; pp. 399-403.

49. Wohlfahrt, G.; Hammerle, A.; Haslwanter, A.; Bahn, M.; Tappeiner, U.; Cernusca, A. Disentangling leaf area and environmental effects on the response of the net ecosystem $\mathrm{CO}_{2}$ exchange to diffuse radiation. Geophys. Res. Lett. 2008, 35, 1-5. [CrossRef]

50. Barron-Gafford, G.A.; Scott, R.L.; Jenerette, G.D.; Hamerlynck, E.P.; Huxman, T.E. Temperature and precipitation controls over leaf- and ecosystem-level $\mathrm{CO}_{2}$ flux along a woody plant encroachment gradient. Glob. Chang. Biol. 2012, 18, 1389-1400. [CrossRef]

51. McLain, J.E.T.; Martens, D.A.; McClaran, M.P. Soil cycling of trace gases in response to mesquite management in a semiarid grassland. J. Arid Environ. 2008, 72, 1654-1665. [CrossRef]

52. Ibañez, M. Vegetation Drives Greenhouse Gas Exchange, and Carbon and Nitrogen Cycling in Grassland Ecosystems. Ph.D. Thesis, University of Lleida, Lleida, Spain, 2019.

53. Busch, F.A.; Sage, R.F.; Farquhar, G.D. Plants increase $\mathrm{CO}_{2}$ uptake by assimilating nitrogen via the photorespiratory pathway. Nat. Plants 2018, 4, 46-54. [CrossRef] [PubMed]

54. Lee, T.D.; Reich, P.B.; Tjoelker, M.G. Legume presence increases photosynthesis and N concentrations of co-occurring non-fixers but does not modulate their responsiveness to carbon dioxide enrichment. Oecologia 2003, 137, 22-31. [CrossRef] [PubMed]

55. Reich, P.B.; Walters, M.B.; Ellsworth, D.S. From tropics to tundra: Global convergence in plant functioning. Ecology 1997, 94, 13730-13734. [CrossRef] [PubMed]

56. Reich, P.B.; Ellsworth, D.S.; Walters, M.B. Leaf Structure (Specific Leaf Area) Modulates Photosynthesis-Nitrogen relations: Evidence from within Across Species and Functional Groups. Funct. Ecol. 1998, 12, 948-958. [CrossRef]

57. Ibañez, M.; Altimir, N.; Ribas, A.; Eugster, W.; Sebastià, M.T. Phenology and plant functional type dominance drive $\mathrm{CO}_{2}$ exchange in seminatural grasslands in the Pyrenees. J. Agric. Sci. 2020, 1-12. [CrossRef]

58. Mulder, C.P.H.; Jumpponen, A.; Högberg, P. How plant diversity and legumes affect nitrogen dynamics in experimental grassland communities. Community Ecol. 2002, 133, 412-421. [CrossRef]

59. Pirhofer-Walzl, K.; Rasmussen, J.; Høgh-Jensen, H.; Eriksen, J.; Søegaard, K.; Rasmussen, J. Nitrogen transfer from forage legumes to nine neighbouring plants in a multi-species grassland. Plant Soil 2012, 350, 71-84. [CrossRef]

60. Nyfeler, D.; Huguenin-Elie, O.; Suter, M.; Frossard, E.; Lüscher, A. Grass-legume mixtures can yield more nitrogen than legume pure stands due to mutual stimulation of nitrogen uptake from symbiotic and non-symbiotic sources. Agric. Ecosyst. Environ. 2011, 140, 155-163. [CrossRef]

61. Debouk, H.; Emeterio, L.S.; Marí, T.; Canals, R.M.; Sebastià, M.T. Plant functional diversity, climate and grazer type regulate soil activity in natural grasslands. Agronomy 2020, 10, 1291. [CrossRef]

62. Davidson, E.A.; Janssens, I.A. Temperature sensitivity of soil carbon decomposition and feedbacks to climate change. Nature 2006, 440, 165-173. [CrossRef] [PubMed]

63. Aljazairi, S.; Arias, C.; Nogués, S. Carbon and nitrogen allocation and partitioning in traditional and modern wheat genotypes under pre-industrial and future $\mathrm{CO}_{2}$ conditions. Plant Biol. 2015, 17, 647-659. [CrossRef] [PubMed]

64. Larsen, K.S.; Ibrom, A.; Beier, C.; Jonasson, S.; Michelsen, A. Ecosystem respiration depends strongly on photosynthesis in a temperate heath. Biogeochemistry 2007, 85, 201-213. [CrossRef]

65. Wang, B.; Wu, Y.; Chen, D. Stable isotopes of carbon and nitrogen help to predict the belowground communities at a regional scale. Sci. Rep. 2017, 7, 1-10. [CrossRef]

66. Zhu, C.; Ma, Y.; Wu, H.; Sun, T.; La Pierre, K.J.; Sun, Z.; Yu, Q. Divergent effects of nitrogen addition on soil respiration in a semiarid grassland. Sci. Rep. 2016, 1-8. [CrossRef]

67. Corrêa Dias, A.T.; van Ruijven, J.; Berendse, F. Plant species richness regulates soil respiration through changes in productivity. Oecologia 2010, 163, 805-813. [CrossRef]

68. Gratani, L.; Crescente, M. Map-Making of Plant Biomass and Leaf Area Index for Management of Protected Areas. Aliso A J. Syst. Evol. Bot. 2000, 19, 1-12. [CrossRef]

69. Sheffer, E.; Canham, C.D.; Kigel, J.; Perevolotsky, A. Countervailing effects on pine and oak leaf litter decomposition in humanaltered Mediterranean ecosystems. Oecologia 2015, 177, 1039-1051. [CrossRef]

70. Fioretto, A.; Papa, S.; Pellegrino, A.; Fuggi, A. Leaf litter decomposition dynamics in Mediteranean area. In Soil Ecology Research Developements; Tian-Xiao, L., Ed.; Nova Science Publishers, Inc.: New York, NY, USA, 2008.

71. Liu, X.P.; Zhang, W.J.; Hu, C.S.; Tang, X.G. Soil greenhouse gas fluxes from different tree species on Taihang Mountain, North China. Biogeosciences 2014, 11, 1649-1666. [CrossRef]

72. Spohn, M. Microbial respiration per unit microbial biomass depends on litter layer carbon-to-nitrogen ratio. Biogeosciences 2015, 12, 817-823. [CrossRef]

73. Jugold, A.; Althoff, F.; Hurkuck, M.; Greule, M.; Lenhart, K.; Lelieveld, J.; Keppler, F. Non-microbial methane formation in oxic soils. Biogeosciences 2012, 9, 5291-5301. [CrossRef] 
74. Barnard, R.; Leadley, P.W.; Hungate, B.A. Global change, nitrification, and denitrification: A review. Global Biogeochem. Cycles 2005, 19, 1-13. [CrossRef]

75. Baggs, E.M.; Rees, R.M.; Smith, K.A.; Vinten, A.J.A. Nitrous oxide emission from soils after incorporating crop crop residues. Soil Use Manag. 2000, 16, 82-87. [CrossRef]

76. Lin, S.; Iqbal, J.; Hu, R.; Cai, J.; Shaaban, M.; Chen, X. Nitrous Oxide Emissions from Yellow Brown Soil as Affected by Incorporation of Crop Residues With Different Carbon-to-Nitrogen Ratios: A Case Study in Central China. Arch. Environ. Contam. Toxicol. 2013, 65, 183-192. [CrossRef]

77. Shaaban, M.; Peng, Q.; Hu, R.; Lin, S.; Zhao, J. Soil Nitrous oxide and Carbon dioxide emissions following incorporation of aboveand below-ground biomass of green bean. Int. J. Environ. Sci. Technol. 2016, 13, 179-186. [CrossRef] 